\title{
Development of Colorimetric Loop-Mediated Isothermal Amplification Assay for Rapid Detection of the Tomato Yellow Leaf Curl Virus
}

\author{
Mohammad Amin Almasi ${ }^{1 *}$, Mehdi Aghapour Ojaghkandi ${ }^{1}$, Ahmad Hemmatabadi ${ }^{2}$, Fatah Hamidi ${ }^{2}$, and Saeedeh Aghaei ${ }^{1}$ \\ ${ }^{1}$ Department of Biotechnology, Research Institute of Physiology and Biotechnology, University of Zanjan, Zanjan, Iran \\ ${ }^{2}$ Science and Research Branch, Islamic Azad University of Tehran, Tehran, Iran
}

\begin{abstract}
Loop-mediated isothermal amplification (LAMP) assay is a novel technique for amplifying DNA under constant temperature, with high specificity, sensitivity, rapidity and efficiency. We applied a rapid detection protocol, for the first time, which utilizes colorimetric loop-mediated isothermal amplification for detection of Tomato Yellow Leaf Curl virus. In this regard, all four LAMP primers (i.e. F3, B3, FIP and BIP,) together with PCR primers (F and R) were designed on the basis of the SF gene of the DNA sequences of TYLCV. Even though DAS-ELISA, PCR and LAMP assays could successfully detect positive infected samples, considering the time, safety, sensitivity, cost and simplicity, the last one was overall superior. Meanwhile, among five different visual dyes to accurately detect LAMP products, both hydroxynaphthol blue and GeneFinderTM could produce long stable color change and brightness in a close tube-based approach to prevent cross-contamination risk, concluded eventually as the best ones. All the results, overall, indicated that the LAMP offers an interesting novel and convenient assay format for the rapid, sensitive, cost-effective, and fairly user friendly diagnostic tool of recognition of Tomato Yellow Leaf Curl virus and therefore presents an alternative to PCR-based assays.
\end{abstract}

Keywords: Tomato yellow leaf curl virus; DAS-ELISA; PCR assay; LAMP assay; Colorimetric LAMP assay

\section{Introduction}

Tomato yellow leaf curl virus (TYLCV) belongs to the Begomovirus genus within the Geminiviridae family. Begomoviruses are exclusively transmitted by Bemisia tabaci (Gennadius) (Homoptera: Aleyrodidae) $[1,2]$. Tomato yellow leaf curl diseases (TYLCD) are associated to a complex of viral species, including Tomato yellow leaf curl virus (TYLCV), Tomato yellow leaf curl Mali virus (TYLCMLV), Tomato yellow leaf curl Sardinia virus (TYLCSV), Tomato yellow leaf curl Malaga virus (TYLCMalV), and Tomato yellow leaf curl Axarquia virus (TYLCAxV) and all including rather similar symptoms on tomato $(L$. esculentum) plants. Hence, TYLCD-associated virus isolates belonging to two or more different species, and sometimes recombinants, have been found in the same country [3-8]. This disease was first identified in Israel in 1930 and has since the 1960s become the most important tomato viral disease in different countries [9-14]. In Iran, TYLCV was first reported in 1996 from central and southern provinces of Iran (Kerman, Hormozgn, Khuzestan, Bushehr, and Sistan- Baluchestan) $[9,13]$. The Lycopersicon esculentum is the primary host of TYLCV [15]. Symptoms induced by TYLC viruses consist of foliar curling and yellowing, reduced leaflet area, plant stunting and reduced fruit size and yield [16,17]. The virus was isolated in 1988 and its genome DNA sequenced in $1991[18,19]$. TYLCV is unusual in that it has a monopartite genome, composed of a single-stranded virion DNA (2787 nt) [20]. The genome consists of six open reading frames (ORFs) that are organized bidirectionally; two of these ORFs (V1 and V2) are in the virion sense orientation, and four (C1-C4) in the complementary orientation. Between the two transcription units resides an intergenic region (IR) of about 300 nucleotides [21-24].

Detection of TYLCV was carried out by using biological methods including DAS-ELISA [25-27], TAS-ELISA (Triple Antibody Sandwich ELISA) [28]; and molecular methods including PCR [3,29], dot blot hybridization [3], tissue blotting immuno-binding assay (TBIA) [25], Hybridization with probe [18] and LAMP [30]. LAMP assay can amplify nucleic acid under isothermal condition in the range of 60 to $65^{\circ} \mathrm{C}$ with a very high specificity, sensitivity, rapidity and low artefact susceptibility [31-33]. LAMP-positive amplicons confirmed by adding a number of fluorescent dsDNA intercalating dye including ethidium bromide $[34,35]$ and SYBR Green $[28,36]$ after the reaction is completed or metal indicators such as Gene-FinderTM [35,37], hydroxynaphthol blue [38-40] and magnesium pyrophosphate [33] prior to the reaction, allowing observation with the naked eye. Here, for the first time, five different visualization systems (colorimetric assay) was consequently employed to rapid detection of Tomato Yellow Leaf Curl Virus (TYLCV) on the basis of the LAMP assay.

\section{Materials and Methods}

\section{Virus samples}

Survey studies were conducted in three provinces (Dezfoul, Zanjan and Mashhad) where tomatoes are commonly grown in Iran. A total of 180 healthy and infected leaf samples with foliar curling and yellowing, reduced leaflet area, plant stunting symptoms which were infected naturally with TYLCV in the field were collected in summer of 2010 and 2011, respectively, from 42 farms in 20 major tomato-growing areas of 3 provinces and kept at $-80^{\circ} \mathrm{C}$ until use. The samples were screened for the presence of TYLCV using serological and molecular techniques.

*Corresponding author: Mohammad Amin Almasi, Department of Biotechnology, Research Institute of Physiology and Biotechnology, University of Zanjan, Zanjan Iran, E-mail: aminalmasi66@gmail.com

Received November 21, 2012; Accepted December 26, 2012; Published January 01, 2013

Citation: Almasi MA, Ojaghkandi MA, Hemmatabadi A, Hamidi F, Aghaei S (2013) Development of Colorimetric Loop-Mediated Isothermal Amplification Assay for Rapid Detection of the Tomato Yellow Leaf Curl Virus. J Plant Pathol Microb 4:153 doi:10.4172/2157-7471.1000153

Copyright: (c) 2013 Almasi MA, et al. This is an open-access article distributed under the terms of the Creative Commons Attribution License, which permits unrestricted use, distribution, and reproduction in any medium, provided the original author and source are credited. 


\section{Double antibody sandwich enzyme linked immune sorbent assay (DAS-ELISA)}

Applying DAS-ELISA to detect TYLCV-SA in infected leaves was essentially similar to those described previously [26]. with some modification as follows: leaf extracts were prepared in a micomortar by grinding tissues in $0.4 \mathrm{ml}$ of phosphate-buffered saline $(0.02 \mathrm{M}, \mathrm{pH} 7.4$, $0.5 \mathrm{ml}$ Tween-20, $10 \mathrm{~g}$ polyvinylpyrrolidone "PVP", $2 \mathrm{~g}$ egg albumin) per liter. Healthy plants were used as a control. Data were expressed and recorded using Multiskan at $\mathrm{A}_{405} \mathrm{~nm}$.

\section{DNA extraction}

Total nucleic acids were extracted from both TYLCV-infected and healthy tomato cultivars using a modified procedure of Dellaporta heat extraction method [41]. Five mg of leaf sample were extracted with 1 $\mathrm{ml}$ of extracting buffer using a pre-cooled mortars and pestles. After vortexing, samples were allowed to settle at $65^{\circ} \mathrm{C}$ for $10 \mathrm{~min}$ before adding $1 / 5$ volume of potassium acetate $(5 \mathrm{M}, \mathrm{pH} 8)$. Samples were incubated on ice for $10 \mathrm{~min}$, and then centrifuged at $17800 \mathrm{~g}$ for 20 $\min$ at $4^{\circ} \mathrm{C}$. Then $500 \mu \mathrm{l}$ of supernatant was taken and added to equal volume of isopropanol. Samples were incubated for $10 \mathrm{~min}$ at $-20^{\circ} \mathrm{C}$, and then centrifuged for $10 \mathrm{~min}$ at $17800 \mathrm{~g}$. The pellet was then treated with phenol, chloroform and isoamyl alchohol (25:24:1) in order to remove RNase, before centrifuging samples again at $17800 \mathrm{~g}$ for 10 min; the aqueous phase was then collected. Aqueous phase $(150 \mu \mathrm{l})$ with three volumes of absolute ethanol were mixed and stored for 30 $\min$ at $-20^{\circ} \mathrm{C}$. After centrifuging for $10 \mathrm{~min}$ at $17800 \mathrm{~g}$, the pellet was washed by $30 \mu \mathrm{l}$ of $70 \%$ ethanol, dried and re-suspended in $60 \mu \mathrm{l}$ of molecular grade water (HPLC), to be stored laity at $-20^{\circ} \mathrm{C}$.

\section{PCR assay}

One set of primers (F and B) was used on the basis of the SF gene (GenBank accession number: AB014347) of the DNA sequences of TYLCV for the amplification of the DNA genomic component. Primer sequences were designed from the nucleotide sequence of the TYLCV genome [30] (Table 1). The PCR reactions contained $1 \mu \mathrm{DNA}, 200$ $\mathrm{mM}$ of each dNTPs, $0.2 \mathrm{mM}$ of each primer, $2 \mathrm{mM} \mathrm{MgCl}_{2}, 10 \mathrm{mM}$ Tris- $\mathrm{HCl}(\mathrm{pH} 8.3), 50 \mathrm{mM} \mathrm{KCl}$ and 2.5 units of Taq DNA polymerase (Cinagen Co, Cat. No TA7505C). The PCR reactions were performed in a Thermal Cycler (iCycler, BIO RAD, CA, USA) with 40 cycles of denaturing for $20 \mathrm{~s}$ at $94^{\circ} \mathrm{C}$, annealing for $40 \mathrm{~s}$ at $55^{\circ} \mathrm{C}$ and DNA extension for $20 \mathrm{~s}$ at $72^{\circ} \mathrm{C}$, followed by a single 7 min extension step. The products were lastly analyzed by gel electrophoresis in which $5 \mu \mathrm{l}$ of the PCR products was loaded on a $1.5 \%$ agarose gel and visualized by staining with ethidium bromide.

\section{LAMP assay}

In order to perform LAMP, on the basis of the SF gene, four specific

\begin{tabular}{|l|l|l|l|l|}
\hline $\begin{array}{l}\text { Prim- } \\
\text { er }\end{array}$ & Type & $\begin{array}{l}\text { Position on } \\
\text { gene }\end{array}$ & Length & Sequence(5'-3') \\
\hline F & Forward & $701-720$ & 20 mer & GTCTTATGAGCAACGGGATG \\
\hline B & Backward & $867-887$ & $21 \mathrm{mer}$ & GAACATGACCTGATTAGTGTG \\
\hline F3 & $\begin{array}{l}\text { Forward } \\
\text { outer }\end{array}$ & $387-405$ & $19 \mathrm{mer}$ & TGCAGTCCGTTGAGGAAAC \\
\hline B3 & $\begin{array}{l}\text { Backward } \\
\text { outer }\end{array}$ & $598-617$ & $19 \mathrm{mer}$ & CCTGTACGTCCATGATCGTC \\
\hline FIP & $\begin{array}{l}\text { Forward } \\
\text { inner }\end{array}$ & $\begin{array}{l}453-473 \text { and } \\
413-431\end{array}$ & 40 mer & $\begin{array}{l}\text { AGTCACGGGCCCTTACAA- } \\
\text { CAGCCCAATACATTGGGCCACG }\end{array}$ \\
\hline BIP & $\begin{array}{l}\text { Backward } \\
\text { inner }\end{array}$ & $\begin{array}{l}515-534 \text { and } \\
564-581\end{array}$ & 37 mer & $\begin{array}{l}\text { TCGAAGGTTCGCCGAAGGCGA- } \\
\text { CAATGGGGACAGCAGC }\end{array}$ \\
\hline
\end{tabular}

Table 1: Oligonucleotide primers used for LAMP and PCR of SF gene of TYLCV. primers, including outer primers (F3 and B3) and inner primers (FIP and BIP) were used [30] (Table 1). LAMP assay was performed in a total volume of $25 \mu \mathrm{l}$ using DNA obtained in a way that we described before. Initially $1 \mu \mathrm{l}$ DNA was added to $23 \mu \mathrm{l}$ of LAMP mixture to provide a final concentration of $20 \mathrm{mM}$ Tris- $\mathrm{HCl}, \mathrm{pH} 8.8,10 \mathrm{mM} \mathrm{KCl}$, $10 \mathrm{mM}\left(\mathrm{NH}_{4}\right)_{2} \mathrm{SO}_{4}, 0.1 \%$ Triton X-100, $2 \mathrm{mM}$ Betaine (Sigma-Aldrich, Oakville, Ontario, Canada), $1 \mathrm{mM} \mathrm{MgSO}, 10 \mathrm{mM}$ each dNTP, $0.2 \mu \mathrm{M}$ each of primer F3 and B3, $0.8 \mu \mathrm{M}$ each of primer FIP and BIP, and $8 \mathrm{U}$ of Bst DNA polymerase (New England Biolabs Inc.). Tubes were then incubated at $63^{\circ} \mathrm{C}$ for $60 \mathrm{~min}$ in water bath.

\section{Colorimetric LAMP assay}

Here, about $0.5 \mu$ g ethidium bromide/ml (Sigma) was added to each tube. Under a UV transilluminator, positive products will be consequently marked if a detectable yellow color pattern is observed. An agarose gel electrophoresis system (optional; 1.5\%) under UV illumination could be also employed to visualize positive reactions: 5 $\mu \mathrm{l}$ of each LAMP amplicon is loaded on a $1.5 \%$ agarose gel $[28,34,35]$. Like other metal indicators, magnesium pyrophosphate must be added before reaction. At the end of the amplification process, positive reactions were accompanied by a visible darker phase in the tubes in consequence of the formation of magnesium pyrophosphate, which can be easily visualized with the naked eye. It is noticeable that the turbidity of the positive samples is stable but just for a short time, which should be consequently judged soon after taking out of the samples from the water bath. To conquer time-dependent instability of magnesium pyrophosphate-based detection method, an alternative visual system using SYBR Green II was employed [28,35,42]. Hence, $2 \mu$ SYBR $^{\circledast}$ Premix Ex Taq ${ }^{\mathrm{TM}}$ II (Perfect Real Time, Takara Bio Co., Ltd., RR081A) was added into each completely finished LAMP reaction containing $25 \mu \mathrm{l}$ LAMP products; all positive reactions were effectively identified. Under UV illumination (302 nm), a green color pattern is an identical characteristic of all positive reactions, as the same was monitored in this study. In Hydroxynaphthol blue (HNB) protocol, 1 $\mu \mathrm{l}$ of the HNB (3 mM, Lemongreen, Shanghai, China) is mixed prior to amplification; all positive reactions can be easily identified using the naked eye, interestingly with no probable cross-contaminations which usually arise from opened tubes after amplification [35,38]. In this context, a sky blue color pattern implies the existence of the reference virus, whereas a violet color change is observed when the control(s) is taken into consideration. An obvious Green fluorescence pattern was observed to confirm positive LAMP products through visual observation with the naked eye when $1 \mu \mathrm{l}$ of GeneFinder ${ }^{\mathrm{TM}}$, diluted to 1:10 with $6 \times$ loading buffer (TaKara, Dalian, China), was added to each reaction as described previously [37]. Remarkably, concerning negative reaction, the original orange color could be observed.

\section{Sensitivity and specificity of the LAMP assay}

Both quality and quantity of DNA template may have a dramatic influence on the results of each PCR method. To determine limit of the LAMP assay, it was compared with that of PCR, a seven dilution series $\left(2 \times 10^{0}\right.$ to $\left.2 \times 10^{7} \mathrm{CFU} / \mathrm{ml}\right)$ of DNA were prepared in water; $2 \mu \mathrm{l}$ of each dilution was used for LAMP and PCR reactions. To determine specificity of the primers, LAMP and PCR reactions were carried out to PLRV (Potato Leafroll Virus) and CMV (Cucurbibta Mosaic Virus) cDNAs. Furthermore, Hydroxynaphthol blue (HNB) dye was added to LAMP products and positive reactions were directly detected by visual inspection. Similarly, the detection limit of the LAMP and PCR was approved by electrophoresis on $1.5 \%$ agarose gel. 
Citation: Almasi MA, Ojaghkandi MA, Hemmatabadi A, Hamidi F, Aghaei S (2013) Development of Colorimetric Loop-Mediated Isothermal Amplification Assay for Rapid Detection of the Tomato Yellow Leaf Curl Virus. J Plant Pathol Microb 4:153. doi:10.4172/2157-7471.1000153

\section{Results}

DAS-ELISA results revealed that 38 out of $180(21.1 \%)$ symptomatic tomato samples obtained from different regions of 3 provinces were infected with TYLCV. As regards PCR, the amplification occurred via both backward and forward primers ( $\mathrm{F}$ and $\mathrm{B}$ ) to generate ultimate products. The method, overall, could successfully identify positive samples. As expected, a fragment with the size band of $187 \mathrm{bp}$ was detected when the PCR products were run on $1.5 \%$ agarose gel and stained with ethidium bromide (Figure 1a). The same as PCR, LAMP protocol could successfully identify positive samples. The LAMP reaction with the specific primers at $63^{\circ} \mathrm{C}$ for 60 min produced multiple bands of different size on electrophoresis because the products consisted of several inverted-repeat structures (Figure 1b). All of the above results indicate that detection of TYLCV by the LAMP assay is approximately 100 times more sensitive as compared with PCR. LAMP amplicons were able to be detected with the naked eye by adding different visual dyes followed by color changing in the solutions. In this regard, all used visual components could successfully make a clear distinction between positive infected samples and negative ones (Figures 2a-e). Also, whereas LAMP produced a ladder-like pattern, the PCR product was a specific DNA band corresponding to a $187 \mathrm{bp}$ amplicon. Our results, interestingly, indicated that LAMP can produce reliable products even under lower DNA concentrations $(2 \times 101 \mathrm{CFU} / \mathrm{ml}$ or more), whilst PCR, requires higher level of DNA (at least $2 \times 10^{3} \mathrm{CFU} / \mathrm{ml}$ ) (Figures $3 \mathrm{a}$ and $3 \mathrm{~b}$ ). Surprisingly, no false positive amplification was detected in
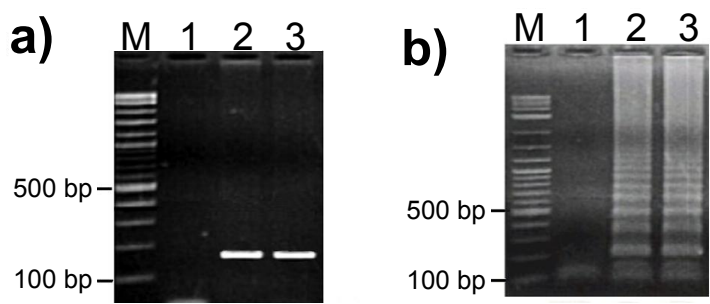

Figure 1: a) Gel electrophoresis pattern of the PCR amplicon on 1.5\% agarose gel. b) Gel electrophoresis pattern of the LAMP amplicons on $1.5 \%$ agarose gel. Left to right: lane M DNA size marker (100 bp; Fermentas); lane 1 negative control (water); lane 2 positive sample; lane 3 positive control.
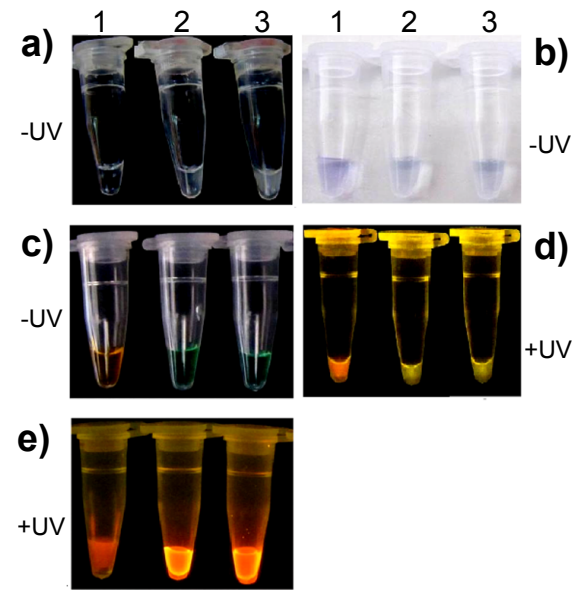

Figure 2: Detection of positive LAMP reactions using five different visualizing methods (different dyes): a) magnesium pyrophosphate-based method; b) hydroxynaphthol blue (HNB)-based method; c) GeneFinderTM based method d) SYBR Green II-based method; e) ethidium bromide-based method. Left to right: tube 1 negative control; tube 2 positive sample; tube 3 positive control.
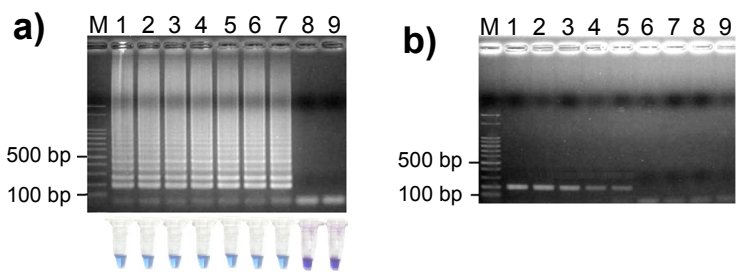

Figure 3: Comparative analysis of the sensitivity of LAMP and PCR, using a seven dilution series of DNA as template (a) Electrophoresis analysis and visual detection (HNB) of LAMP; (b) Electrophoresis analysis of PCR. Left to

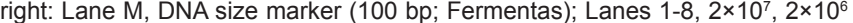
, $2 \times 10^{5}, 2 \times 10^{4}, 2 \times 10^{3}, 2 \times 10^{2}, 2 \times 10^{1}$ and $2 \times 10^{0} \mathrm{CFU} / \mathrm{ml}$, respectively; Lane 9 negative control (water).
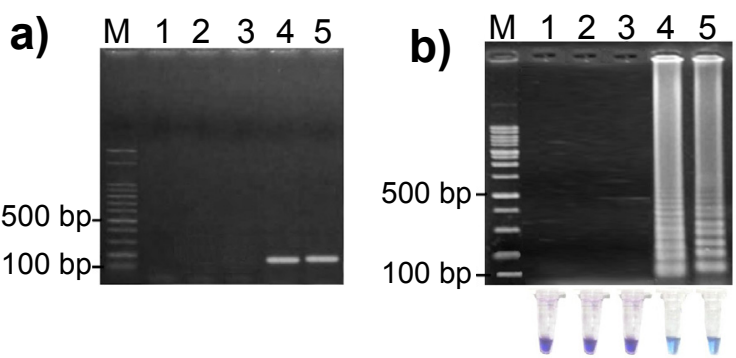

Figure 4: Comparative analysis of the specificity of LAMP and PCR (a) Electrophoresis analysis of PCR; (b) Electrophoresis analysis and visual detection (HNB) of LAMP. Left to right: lane M, DNA size marker (100 bp; Fermentas); lanes 1 negative control (water); lane 2 PLRV; lane $3 \mathrm{CMV}$; lane 4 positive sample; lane 5 positive control.

\begin{tabular}{|l|l|l|l|l|l|l|l|l|}
\hline Assay & Time & $\begin{array}{l}\text { Detection } \\
\text { method }\end{array}$ & Safety & $\begin{array}{l}\text { Need to } \\
\text { UV ray }\end{array}$ & $\begin{array}{l}\text { Need to } \\
\text { detect } \\
\text { instruments }\end{array}$ & Cost & $\begin{array}{l}\text { User } \\
\text { Friendly }\end{array}$ & Accuracy \\
\hline $\begin{array}{l}\text { DAS- } \\
\text { ELISA }\end{array}$ & $1-2$ days & $\begin{array}{l}\text { Visual or with } \\
\text { ELISA reader }\end{array}$ & Yes & No & Yes & High & Low & High \\
\hline PCR & 3 hours & $\begin{array}{l}\text { Gel } \\
\text { electrophoresis }\end{array}$ & No & Yes & Yes & High & Low & High \\
\hline LAMP & $\begin{array}{l}60 \\
\text { minute }\end{array}$ & Visual & Yes & No & No & Low & High & High \\
\hline
\end{tabular}

Table 2: Comparison of DAS-ELISA, PCR and LAMP assays.

specificity test and a $100 \%$ predictive value was obtained for PCR and LAMP assays (Figures $4 \mathrm{a}$ and $4 \mathrm{~b}$ ).

\section{Discussion}

In this study, as a result, three detection methods including DASELISA, PCR and LAMP were assessed to explore positive and negative aspects of each one, followed by introducing the best one regarding TYLCV detection. Even though all threetechniqueshad enough potential to make differentiation and detect infected plant samples accurately, LAMP proved to be much more useful as some factors including time, safety, cost and being user friendly are taken into account (Table 2). Time DAS-ELISA as compared with LAMP and PCR commonly needs a long time to identify positive infected samples (two or few additional days). In reality, with the exception of section one which takes equal time, LAMP overall requires just $60 \mathrm{~min}$ to accomplish (as the least demanding detection method), while regarding PCR and DAS-ELISA, $3 \mathrm{~h}$ and at least 1 day should be served, respectively. This, in turn, would simplify the detection procedure and result in saving of significant time needing for separating of the amplified products on the gel and the analyzing of the data which are commonly used in the other PCR-based 
Citation: Almasi MA, Ojaghkandi MA, Hemmatabadi A, Hamidi F, Aghaei S (2013) Development of Colorimetric Loop-Mediated Isothermal Amplification Assay for Rapid Detection of the Tomato Yellow Leaf Curl Virus. J Plant Pathol Microb 4:153. doi:10.4172/2157-7471.1000153

Page 4 of 6

\begin{tabular}{|l|l|l|l|l|l|l|l|}
\hline Visual system & $\begin{array}{l}\text { Detection } \\
\text { method }\end{array}$ & Safety & $\begin{array}{l}\text { Positive } \\
\text { reaction }\end{array}$ & Negative sample & $\begin{array}{l}\text { Need to UV } \\
\text { ray }\end{array}$ & Stability & $\begin{array}{l}\text { Cross } \\
\text { contamination }\end{array}$ \\
\hline Magnesium pyrophosphate & Visual & Yes & Turbidity & No turbidity & No & $5-10$ seconds & No \\
\hline Ethidium bromide & Visual & No & Yellow & No color & Yes & 2 weeks & Yes \\
\hline SYBR green (ii) & Visual & Yes & Green & Red & Yes & $1-3$ days & Yes \\
\hline Hydroxynaphthol blue & Visual & Yes & Sky blue & Violet & No & $2-3$ weeks & No \\
\hline Genefinder ${ }^{T M}$ & Visual & Yes & Green & Red & No & $2-3$ weeks & No \\
\hline
\end{tabular}

Table 3: Comparison of colorimetric assays together.

methods. Safety regarding a number of detection methods, application of gel electrophoresis systems has emerged as a routine approach with enough potential to observe related amplicons. Just the same, such visual methods not only involve some expensive instruments but also during a period of time, exposure to the UV ray (because it is harmful to the eyes, even watching for a short period would irritate eyes and cause symptoms similar to conjunctivitis) as well as ethidium bromide could accompany a number of serious negative effects on researchers who use these methods $[28,34,35]$. More surprisingly, LAMP amplified products can be easily visualized by means of different in-tube color indicators with no essential requirement of additional staining systems; thus, toxic staining materials would be significantly avoided. Cost and User Friendly Equipped labs with some molecular instruments as well as trained personnel are prerequisites to perform DAS-ELISA and PCR assays, all of which are undoubtedly costly. On the contrary, LAMP can be easily accomplished just in a water bath or temperature block with no need of thermocyler and gel electrophoresis as the same results were recorded by $[30,43]$. On the other hand, the presence of LAMP-positive amplicons proved to be confirmed by adding a number of fluorescent or metal dyes to the reaction tubes, allowing observation with the naked eye [39,44-46]. In the current study, therefore, LAMP amplified products were confirmed by adding all aforementioned visual systems, either prior to or after the reaction along with forming diverse color patterns depending upon the chemical characteristics of the applied chemical substances as dye. According to our results, despite the precise detection of positive LAMP products using all dyes, some were significantly superior when the time of stability, cost and the safety were taken into consideration (Table 3). For instance, regardless of its reasonable color change stability ( $\geq 2$ weeks), when employing ethidium bromide, a UV transilluminator must be available, both of which are toxic, resulting in deleterious consequences on human health and the environment $[38,35,28]$. More interestingly, in some cases, just a little fluorescent emission could be observed in negative tubes, presumably arising from the presence of primers and/or DNA templates, leading to an increase to false positive outputs $[28,34]$. As the last drawback, the corresponding lab(s) should be equipped with such instruments which are commonly costly. Alternatively, to remedy such problems, the first metal dye called magnesium pyrophosphate was utilized, but just an ephemeral color change (i.e. turbidity; no more than a few seconds) was observed as the same result was reported by $[35,28,33]$. Even though short stability of the color change probably cannot be a significant problem as long as just a few numbers of suspicious samples are used, during assessment of a great quantity of infected samples, most of the time, inaccurate results will be accordingly achieved $[35,28]$. The method, nevertheless, since in one hand is exploited prior to the reaction, leading to a significant reduction on probable contaminations, and on the other there is no need of toxic devices, could be thereby attributed as a reliable visual observation approach. Anyway, to provide a situation to increase time stability, the second fluorescent dye coined SYBR Green II was employed, leading to a clear green color pattern. Notably, regardless of observing a significant growth on time stability (about 1-3 days), the method not only requires UV transilluminator but also its stability is more negatively sensitive when amplified reactions are exposed to the daylight. Indeed, since the dye must be added after the amplification which requires opening of the tubes, the occurrence of cross-contamination risk will be accordingly enhanced $[35,42,44]$. To avoid such contaminations, using separate rooms can be a solution for LAMP setup and analysis [42]. To abbreviate the contamination hazard and also increase color stability, as a result, two additional metal indicators (i.e. HNB and GeneFinder ${ }^{\mathrm{TM}}$ ) known as close-tube LAMP detection were lastly used. Interestingly, HNB and GeneFinder ${ }^{\mathrm{TM}}$ dyebased assays were accompanied by several remarkable advantages compared with other colorimetric-based methods in that of which are mixed prior to amplification, a need to open the assayed samples to add the dye is thereby omitted, and the risk of cross-contamination will be excluded drastically [35,37,38,44]. Meanwhile, the visual inspection of LAMP products by means of two last metal dyes was seen as advantageous as there was no need for electrophoresis and subsequent staining with carcinogenic ethidium bromide. Lastly, the color brightness and stability of the both HNB and GeneFinder ${ }^{\mathrm{TM}}$ in the solutions with positive/negative reactions remained constant after 2-3 weeks of exposure to ambient light, whereas turbidity caused by precipitation of magnesium pyrophosphate or SYBER Green II was stable only $5 \mathrm{~s}$ and 1-3 days, respectively. It is noticeable that since the color presented by HNB was light blue for positive results and dark blue for negative results, which cannot be discriminated precisely, so such based detection methods involve a little more attention to provide accurate decision. In summary, a novel colorimetric LAMP assay for rapid and easy detection of TYLCV was developed here, its potential compared with DAS-ELISA and PCR assays. The method, on the whole, had the following advantages over the two mentioned procedures: [38] no requirement of expensive and sophisticated tools for amplification and detection; [25] no post amplification treatment of the amplicons; and [35] a flexible and easy detection approach, that is visually detected by naked eyes using diverse visual dyes. On the other hand, among different visual systems, both HNB and GeneFinder ${ }^{\mathrm{TM}}$ were proved to be more powerful since tubes do not have to be opened after amplification consequent to accompany by no cross-contamination, judging positive reactions can be visualized using the naked eye, no need of post amplification treatment of the amplicons and finally the brightness and stability produced by these two dyes were significantly stronger than the others. Due to such remarkable features, the application of this colorimetric assay using visual observation systems particularly HNB and GeneFinder ${ }^{\mathrm{TM}}$ seems to be more effective as a new viral diagnostic method for epidemiological studies of TYLCV particularly in less well equipped laboratories and might be helpful in clarifying virus-vector interaction. As the last point of view, the current diagnostic approach can be suitable not only for laboratory research but also regarding field diagnoses of many infectious diseases worldwide.

\section{References}

1. Bendahmane M, Gronenborn B (1997) Engineering resistance against tomato yellow leaf curl virus (TYLCV) using antisense RNA. Plant Molecular Biology 33: 351-357. 
Citation: Almasi MA, Ojaghkandi MA, Hemmatabadi A, Hamidi F, Aghaei S (2013) Development of Colorimetric Loop-Mediated Isothermal Amplification Assay for Rapid Detection of the Tomato Yellow Leaf Curl Virus. J Plant Pathol Microb 4:153. doi:10.4172/2157-7471.1000153

2. Varma A, Malathi VG (2003) Emerging geminivirus problems: a serious threat to crop production. Annal Appl Biol 142: 145-164

3. Anfoka GH, Abhary M, Nakhla MK (2005) Molecular identification of species of the Tomato yellow leaf curl virus complex in Jordan. J Plant Pathol 87: 65-70

4. Malekzadeh S, Bananej K, Vahdat A (2011) Serological and Molecular Identification of Tomato Yellow Leaf Curl Virus in Khuzestan Province of Iran. Phytopathol Mediterr 50: 303-309.

5. Monci F, Sanchez-Campos S, Navas-Castillo J, Moriones E (2002) A natura recombinant between the geminiviruses Tomato yellow leaf curl Sardinia virus and Tomato yellow leaf curl virus exhibits a novel pathogenic phenotype and is becoming prevalent in Spanish populations. Virology 303: 317-326.

6. Pico B, Diez MJ, Nuez F (1999) Improved diagnostic techniques for tomato yellow leaf curl virus in tomato breeding programs. Plant Disease 83: 10061012.

7. Pico B, Ferriol M, Diez MJ, Vinals FN (2001) Agroinoculation methods to screen wild Lycopersicon for resistance to Tomato yellow leaf curl virus. J Plant Patho 83: $215-220$

8. Pilowsky M, Cohen S (2000) Screening additional wild tomatoes for resistance to the whitefly-borne tomato yellow leaf curl virus. Acta Physiol Plant 22: 351 353

9. Bananej K, Vahdat A, Hosseini-Salekdeh G (2009) Begomoviruses associated with yellow leaf curl disease of tomato in Iran. J Phytopathology 157: 243-247.

10. Cohen S, Harpaz I (1964) Periodic, rather than continual acquisition of a new tomato virus by its vector, the tobacco whitefly (Bemisia tabaci Gennadius). Entomol Exp Appl 7: 155-166.

11. Cohen S, Ntignus $Y$ (1994) Tomato yellow leaf curl virus, a whitefly-borne geminivirus of tomatoes. Advanc Dis Vect Res 10: 259-288.

12. Czosnek H, Navot H, Laterrot $H$ (1990) Geographical distribution of Tomato yellow leaf curl virus. A first survey using a specific DNA probe. Phytopatho Mediterr 24: 1-6.

13. Hajimorad MR, Kheyr-Pour A, Alavi V, Ahoonmanesh A, Bahar M, et al. (1996) Identification of whitefly transmitted Tomato yellow leaf curl geminivirus from Iran and a survey of its distribution with molecular probes. Plant Pathol 45 418-425.

14. Polston JE, McGovern RJ, Brown LG (1999) Introduction of Tomato yellow leaf curl virus in Florida and implications for the 106 spread of this and other geminiviruses of tomato. Plant Dis 83: 984-988.

15. Zakay Y, Navot N, Zeidan M, Kedar N, Rabinowitch H, et al. (1991) Screening Lycopersicon accessions for resistance to Tomato yellow leaf curl virus presence of viral DNA and symptom development. Plant Disease 75: 279-281.

16. Khan AJ, Idris AM, Al-Saady NA, Al-Mahruki MS, Al-Subhi AM, et al. (2008) A divergent isolate of Tomato yellow leaf curl virus from Oman with an associated DNA beta satellite: an evolutionary link between Asian and the Middle Eastern virus-satellite complexes. Virus Genes 36: 169-176.

17. Nakhla MK, Mazyad HM, Maxwell DP (1993) Molecular characterization of four tomato yellow leaf curl virus isolates from Egypt and development of detection me]thods. Phytopathol Mediterr 32: 163-173.

18. Czosnek H, Ber R, Antignus Y, Cohen S, Navot N, et al. (1988) Isolation of tomato yellow leaf curl virus, a geminivirus. Phytopathology 78: 508-512.

19. Navot N, Pichersky E, Zeidan M, Zamir D, Czosnek H (1991) Tomato yellow leaf curl virus: a whitefly-transmitted geminivirus with a single genomic molecule. Virol 185: 151-161.

20. Antignus EY, Cohen S (1994) Complete nucleotide sequence of an infectious clone of a mild isolate of tomato yellow leaf curl virus (TYLCV). Phytopathol 84: 707-712.

21. Argüello-Astorga GR, Guevara-González RG, Herrera-Estrella LR, RiveraBustamante RF (1994) Geminivirus replication origins have a group specific organization of iterative elements; a model for replication. Virology 203: 90-100.

22. Hanley-Bowdoin L, Settlage SB, Orozco BM, Nagar S, Robertson D (1999) Geminiviruses: models for plant DNA replication, transcription, and cell cycle regulation. Crit Rev Plant Sci 18: 71-106.

23. Laufs J, Traut W, Heyraud F, Matzeit V, Rogers SG, et al. (1995) In vitro cleavage and joining at the viral origin of replication by the replication initiator protein of tomato yellow leaf curl virus. Proc Natl Acad Sci USA 92: 3879-3883.
24. Noris E, Hidalgo E, Accotto GP, Moriones E (1994) High similarity among the tomato yellow leaf curl virus from the west Mediterranean basin: The nucleotide sequence of an infectious clone from Spain. Arch Virol 135: 165-170.

25. Ajlan AM, Ghanem GAM, Abdulsalam KS (2007) Tomato yellow leaf curl virus (TYLCV) in Saudi Arabia: Identification, partial characterization and virus vector Relationship. Arab J Biotech 10: 179-192

26. Cohen S, Duffus EJ, Liu H (1989) Acquistion, interference and retention of cucurbit leaf curl viruses in whiteflies. Phytopathology 79: 109-113.

27. Lapidot M, Friedmann M, Pilowsky M, Ben-Joseph R, Cohen S (2001) Effect of host plant resistance of tomato yellow leaf curl virus (TYLCV) on virus acquisition and transmission by its whitefly vector. Phytopathology 91: 12091213.

28. Moradi A, Nasiri J, Abdollahi H, Almasi M (2012) Development and evaluation of a loopmediated isothermal amplification assay for detection of Erwinia amylovora based on chromosomal DNA. Euro J Plant Pathol 133: 609-620.

29. leamkhang S, Riangwong L, Chatchawankanphanich O (2005) Detection of Tomato Yellow leaf Curl Thailand Virus by PCR Without DNA Extraction. Mo Bio 31: 233-239.

30. Fukuta S, Kato S, Yoshida K, Mizukami Y, Ishida A, et al. (2003) Detection of tomato yellow leaf curl virus by loop-mediated isothermal amplification reaction. J Virol Methods 112: 35-40.

31. Fu S, Qu G, Guo S, Ma L, Zhang N, et al. (2011) Applications of loop-mediated isothermal DNA amplification. Appl Biochem Biotech 163: 845-850.

32. Hadersdorfer J, Neumuller M, Treutter D, Fischer T (2011) Fast and reliable detection of Plum pox virus in woody host plants using the Blue LAMP protocol. Annal Appl Biol 159: 456-466.

33. Notomi T, Okayama $\mathrm{H}$, Masubuchi $\mathrm{H}$, Yonekawa $\mathrm{T}$, Watanabe $\mathrm{K}$, et al. (2000) Loop-mediated isothermal amplification of DNA. Nucl Acids Res 28: 63.

34. Tsai SM, Chan KW, Hsu WL, Chang TJ, Wong ML, et al. (2009) Development of a loop-mediated isothermal amplification for rapid detection of orf virus. J Virol Methods 157: 200-204.

35. Almasi MA, Moradi A, Nasiri J, Karami S, Nasiri M (2012) Assessment of Performance Ability of Three Diagnostic Methods for Detection of Potato Leafroll Virus (PLRV) Using Different Visualizing Systems. Appl Biochem Biotechnol 168: 770-784.

36. Parida M, Shukla J, Sharma S, Ranghia Santhosh S, Ravi V, et al. (2011) Development and evaluation of reverse transcription loop-mediated isothermal amplification assay for rapid and real-time detection of the swine-origin influenza A H1N1 virus. J Mole Diagn 13: 100-107.

37. Ren WC, Wang CM, Cai YY (2009) Loop-mediated isothermal amplification for rapid detection of acute viral necrobiotic virus in scallop Chlamys farreri. Acta Virol 53: 161-167.

38. Ahmadi S, Almasi MA, Fatehi F, Struik PC, Moradi A (2012) Visual Detection of Potato leafroll virus by One-step Reverse Transcription Loop-Mediated Isothermal Amplification of DNA with Hydroxynaphthol Blue Dye. Journal of Phytopathology.

39. Cardoso TC, Ferrari HF, Bregano LC, Silva-Frade C, Rosa AC, et al. (2010) Visual detection of turkey coronavirus RNA in tissues and feces by reversetranscription loop-mediated isothermal amplification (RT-LAMP) with hydroxynaphthol blue dye. Molecular and Cellular Probes 24: 415-417.

40. Goto M, Honda E, Ogura A, Nomoto A, Hanaki K (2009) Colorimetric detection of loop mediated isothermal amplification reaction by using hydroxyl naphthol blue. Biotech 46: 167-172.

41. Potter JL, Nakhla MK, Meja L, Maxwell DP (2003) PCR and DNA hybridization methods for specific detection of bean-infecting begomoviruses in the Americas and Caribbean. Plant Dis 87: 1205-1212.

42. Cheng SJ, Chen ZY, Chu YN, Cui LB, Shi ZY, et al. (2011) Sensitive detection of influenza $A(\mathrm{H} 1 \mathrm{~N} 1)$ virus by isothermal amplification in a single tube. Chinese Journal of Analytical Chemistry 39: 335-340.

43. Soliman H, El-Matbouli M (2009) Immunocapture and direct binding loop mediated isothermal amplification simplify molecular diagnosis of Cyprinid herpesvirus-3. J Virol Methods 162: 91-95.

44. Goto M, Shimada K, Sato A, Takahashi E, Fukasawa T, et al. (2010) Rapid detection of Pseudomonas aeruginosa in mouse feces by colorimetric loopmediated isothermal amplification. J Microbiol Methods 81: 247-252. 
Citation: Almasi MA, Ojaghkandi MA, Hemmatabadi A, Hamidi F, Aghaei S (2013) Development of Colorimetric Loop-Mediated Isothermal Amplification Assay for Rapid Detection of the Tomato Yellow Leaf Curl Virus. J Plant Pathol Microb 4:153. doi:10.4172/2157-7471.1000153

Page 6 of 6

45. Iwamoto T, Sonobe T, Hayashi K (2003) Loop-mediated isothermal amplification for direct detection of Mycobacterium tuberculosis complex, M. avium, and $M$. intracellulare in sputum samples. J Clin Microbiol 41: 2616-2622.
46. Ma XJ, Shu YL, Nie K, Qin M, Wang DY, et al. (2010) Visual detection of pandemic influenza A H1N1 Virus 2009 by reverse-transcription loop-mediated isothermal amplification with hydroxynaphthol blue dye. J Virol Methods 167 214-217. 